\title{
HYBRIDIZATION BETWEEN CUTTHROAT AND RAINBOW TROUT: EV IDENCE FROM BIOCHEMICAL GENETIC LOCI
}

\author{
Eric J. Loudenslager \\ G.A.E. Gall \\ Fisheries Biology Research Facility \\ Department of Animal Science \\ University of California \\ Davis, California 95616
}

\section{Objectives}

Cutthroat, Salmo clarki, and rainbow, Salmo gairdneri, trout are largely allopatric, closely related species. Where naturally sympatric ecological isolating mechanisms maintain species identity. However, the inland subspecies of cutthroat trout which did not evolve in sympatry with rainbows are thought to freely hybridize with rainbow trout which have been introduced for recreational purposes. Because of the mass introductions of rainbow trout fish managers have become increasingly concerned about the purity of the dwindling stocks of native cutthroats.

Several methods, including the Hubbs Hybrid Index, principal components and discriminant function analysis of meristic and morphological characters and chromosomal and electrophoretic analysis of genetic characters have been used by ichthyologists to identify putative hybrid individuals. Regardless of the method used any analysis of hybridization must include a sufficiently large geographic sampling of both parental species as well as known $F_{1}$ hybrids if wild hybrids are to be identified reliably.

Recently, studies of geographic protein variation and chromosome variation in cutthroat trout (Loudenslager and Thorgaard, 1979; Loudenslager and Gall, 1980) have demonstrated extensive genetic divergence among subspecies inhabiting isolated basins and drainages. These studies provide the necessary baseline data to describe the extent of genetic variability expected in pure cutthroat trout populations. Busack et al. (1979) provide data on several hatchery stocks of rainbow trout. Comparison of the Busack et al. (1979) data and recent collection from northern California (Loudenslager and Gall, unpublished data) with cutthroat trout indicate that several biochemical genetic loci should be effective markers of rainbow $X$ cutthroat trout hybridization. These include creatine kinase (CK), general muscle protein (GMP), peptidases PEP 1 and PEP 2), and malic enzyme (ME). However, for a genetic locus to be an effective marker of hybridization the $F_{1}$ generation must exhibit a combination of the parental banding patterns. This has been confirmed for the above proteins in a rainbow (Kamloops Junction Stock) X cutthroat (Henan Lake Stock) 
experimental cross routinely performed by the California Department of Fish and Game (Loudenslager, 1979).

With the baseline data collected a concerted search for hybridized populations was initiated in 1978. Several tributary streams in the Walker River drainage, California were found to be inhabited by trout populations consisting of cutthroats, rainbows and their hybrids. No hybrids had yet been identified within Grand Teton or Yellowstone National Parks. Consequently, the search for hybridized populations was continued during the summer of 1979.

\section{Methods}

With the aid of John Varley, USFWS-Yellowstone National Park, populations were selected as putative hybrids and collected during the summer of 1979. Populations were selected on the basis of having been planted with rainbow trout as indicated by park planting records or by having trout that phenotypically exhibited coloration and spotting patterns hypothetically expected in putative hybrids, and included Wolf Lake outlet, Rose Creek, upper and lower Slough Creek (2 samples), Buffalo Fork Creek, Soda Butte Creek, and the Yellowstone River below the lower falls within the Yellowstone Canyon.

Enzymes including aspartate amino transferase AAT), alcohol dehydrogenase (ADH), alpha-glycerolphosphate dehydrogenase (AGPDH), creatine kinase $(C K)$, beta-galactosidase ( $b G A L)$, diaphorase $(D \mid A)$, fumerase (FUM), isocitrate dehydrogenase (IDH), lactate dehydrogenase (LDH), malate dehydrogenase (MDH), malic enzyme (ME), para-albumin (pALB), peptidase (PEP), phosphohexoseisomerase (PHI), 6-phosphogluconate dehydrogenase (6PGDH), phosphoglucomutase (PGM), phosphomanoseisomerase (PMI), sorbitol dehydrogenase (SDH), superoxide dismutase (SOD), and general muscle protein (GMP) encoded by 42 genetic loci were screened in all populations using the buffer systems outlined in Loudenslager and Gall (1980).

\section{Results}

The products of 42 genetic loci have been analyzed in seven trout populations suspected of being composed of Yellowstone cutthroat trout ( $\underline{s} . \underline{c}$. bouvier $\underline{i}$ ), rainbow trout (s. gairdneri) and their hybrids. Allele frequencies for the discriminating loci, creatine kinase, malic enzyme, peptidase 1 and 2 , and general muscle protein are presented in table 1 along with allele frequencies for populations which are pure representatives of each species. From this analysis it is apparent that the samples from lower Slough Creek, Buffalo Fork Creek, Rose Creek, and Soda Butte Creek represent trout populations that are a mixture of cutthroats, rainbows, and their hybrids. The Yellowstone River and upper Slough Creek samples represent populations of cutthroat trout with no detectable rainbow trout influence whereas the Wolf Lake outlet sample represents a population of rainbow trout with no detect-

$$
\text { -109- }
$$


able influence of cutthroat trout.

The hybridized populations can be further analyzed by identifying each individual in a given population as a cutthroat trout, a rainbow trout, an $F_{1}$ hybrid, or a backcross or $F_{2}$ or greater hybrid (in the final catagory both backcross and $F_{2}$ or greater are indistinquishable electrophoretically and must be grouped together eventhough they result from different mating pairs) on the basis of their composite enzyme phenotype. This analysis uses the criteria that individuals heterozygous for all of the discriminating loci are classified as $F_{1}$; that individuals homozygous for the cutthroat alleles at all the loci are cutthroats, that individuals homozygous for the rainbow trout alleles at all of the loci are rainbows; and that individuals homozygous for the cutthroat or rainbow allele at one locus and either homozygous or heterozygous for the alternate allele at other loci are backcross or $\mathrm{F}_{2}$ or greater. Because not every linkage group is marked, this analysis is of course only an estimate of the structure of these populations. The results of this analysis are presented in table 2 and reveals substantial differences in the structure of the hybridized populations. Lower Slough Creek, Rose Creek, and Buffalo Fork Creek are classified as hybrid swarms with cutthroat, rainbow, $F_{1}$, and backcross individuals present. Within all of these populations backcross individuals are present in greatest abundance. There are differences among these populations in the minor components, In lower Slough Creek cutthroat trout are in greater abundance than rainbow trout while the opposite situation is observed in Rose Creek and Buffalo Fork Creek. Soda Butte Creek is predominated by cutthroat trout without any rainbow or $F_{1}$ individuals and only a few backcross individuals. This population is best classified as introgressed. That is, past hybridization has resulted in the incorporation of rainbow trout alleles in to Soda Butte population gene pool.

\section{Conclusions}

Biochemical genetic data collected previously in California and Nevada (Loudenslager, 1979) and currently in Yellowstone National Park support the hypothesis that cutthroat and rainbow trout can and will hybridize when sympatric. In addition, the biochemical data has quantified the extent of introgression and provided insight into the dynamics of rainbow $X$ cutthroat hybridization.

A principal finding of this study is geographic variation in the extent of rainbow $X$ cutthroat trout hybridization. Almost every conceivable outcome of the mixing of cutthroat and rainbow trout has been observed. Within Yellowstone National Park hybrid swarms which consist of cutthroat and rainbow trout and both $F_{1}$ and backcross hybrids have been discovered. Several cutthroat populations in tributaries to the Humboldt River, Nevada exhibit no detectable hybridization and rainbow trout are presently absent eventhough hundreds of thousands of rainbows were planted from 1900 to 1950. In Long Canyon Creek, Nevada the trout population consists of cutthroats and rainbows with no detectable 
evidence of hybridization. The last recorded plant of rainbow trout was in 1947 suggesting that the sympatry without hybridization is in this case stable. On the other extreme, Wolf Lake, Yellowstone National Park was planted with cutthroat trout in about 1910 (Varley, per. comm.) and the records indicate that a self perpetuating population was established. Rainbow trout were planted in the lake about 1925. The biochemical genetic analysis indicates that only rainbow trout are present now. In this case it appears that rainbows have successfully replaced the cutthroat population,

The large proportion of backcross individuals in many hybrid swarms provides ample evidence that hybrids are fertile and can reproduce. Thus, the geographic variation observed in the extent of hybridization is not due to a lack of genetic compatability among these species. Our results suggest that the outcome is probably influenced by ecological variables, although this remains to be experimentally demonstrated and enumerated.

\section{Literature Cited}

Busack, C. A., R. Halliburton, G.A.E. Gall, 1979. Electrophoretic variation and differentiation in four strains of domesticated rainbow trout (Salmo gairdneri). Can. J. Genet. Cytol. 21: 81-94.

Loudenslager, E.J. 1979. Electrophoretic identification of interior cutthroat trout subspecies and their hybrids with introduced rainbow trout. (ABST). American Fisheries Society Annual Meeting. West Yellows tone, Montana,

Loudenslager, E.J. and G.H. Thorgaard, 1979. Karyotypic and evolutionary relationships of the Yellowstone (Salmo clarki bouvieri) and west-slope ( $\underline{s}$. $\underline{c}$. lewisi) cutthroat trout. J. Fish. Res. Bd. Canada. 36:630-635.

Loudenslager, E.J. and G.A.E. Gall. 1980. Geographic patterns of protein variation and subspeciation in cutthroat trout (Salmo clarki). Syst. Zool. in press.

\section{Acknowledgments}

We wish to thank Rick Swanson, Kemper McMaster, and Bob Griesweld for their participation in sample collection. We would especially like to thank John Varley whose participation in both the planning and design of this project were critical its final completion. Fred Utter introduced us to the peptidase enzymes which are valuable to the hybrid identification and Boyd Bentley helped prepare the tissue samples. Funds were provided through a grant from the University of Wyoming-National Park Service Research Center. 
Table 1. Allele frequencies at select biochemical genetic loci in Salmo populations.

\begin{tabular}{|c|c|c|c|c|c|c|c|c|c|c|}
\hline \multicolumn{4}{|l|}{$\overline{\text { Loci }}$} & \multicolumn{6}{|c|}{ Populations } & \multirow{3}{*}{$\begin{array}{l}9 \\
1.00\end{array}$} \\
\hline & & 1 & 2 & 3 & 4 & 5 & 6 & 7 & 8 & \\
\hline$\overline{\mathrm{CK}}$ & $\begin{array}{r}100 \\
85\end{array}$ & 1.00 & 1.00 & $\begin{array}{l}0.59 \\
0.41\end{array}$ & 1.00 & $\begin{array}{l}0.46 \\
0.54\end{array}$ & $\begin{array}{l}0.55 \\
0.45\end{array}$ & $\begin{array}{l}0.04 \\
0.96\end{array}$ & 1.00 & \\
\hline ME & $\begin{array}{l}125 \\
100\end{array}$ & 1.00 & 1.00 & $\begin{array}{l}0.67 \\
0.33\end{array}$ & 1.00 & $\begin{array}{l}0.57 \\
0.43\end{array}$ & $\begin{array}{l}0.31 \\
0.69\end{array}$ & $\begin{array}{l}0.96 \\
0.04\end{array}$ & 1.00 & 1.00 \\
\hline PEP-1 & $\begin{array}{l}160 \\
100\end{array}$ & 1.00 & 1.00 & $\begin{array}{l}0.61 \\
0.39\end{array}$ & 1.00 & $\begin{array}{l}0.50 \\
0.50\end{array}$ & $\begin{array}{l}0.28 \\
0.72\end{array}$ & $\begin{array}{l}0.96 \\
0.04\end{array}$ & 1.00 & 1.00 \\
\hline PEP-2 & $\begin{array}{l}110 \\
100\end{array}$ & 1.00 & 1.00 & $\begin{array}{l}0.46 \\
0.54\end{array}$ & 1.00 & $\begin{array}{l}0.54 \\
0.46\end{array}$ & $\begin{array}{l}0.23 \\
0.77\end{array}$ & 1.00 & 1.00 & 1.00 \\
\hline GMP & $\begin{array}{l}110 \\
100\end{array}$ & 1.00 & 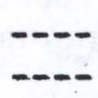 & $\cdots$ & 1.00 & $\begin{array}{l}0.57 \\
0.43\end{array}$ & $\begin{array}{l}0.67 \\
0.33\end{array}$ & 1.00 & 1.00 & 1.00 \\
\hline
\end{tabular}

1. Yellowstone Lake; 2. S. gairdneri (RTD); 3. Lower Slough Creek; 4. Upper Slough Creek; 5. Buffalo Fork Creek; 6. Rose Creek;

7. Soda Butte Creek; 8. Yellowstone River; 9. Wolf Lake out let.

Table 2. Distribution of cutthroats, rainbows, $F_{1}$, and backcross hybrids in Salmo populations.

\begin{tabular}{lcccc}
\hline & Cutthroats & $\frac{\text { Rainbows }}{1}$ & $\frac{F_{1}}{7}$ & $\frac{\text { Backcross }}{22}$ \\
\hline Population & 7 & 2 & 0 & 10 \\
Buffalo Fork Creek & 1 & 3 & 1 & 14 \\
Rose Creek & 0 & 0 & 0 & 4 \\
Soda Butte Creek & 18 & & 1 & \\
\hline
\end{tabular}

